\title{
Limnic Rendzinas in the Mazurian Lakeland (NE Poland)
}

\begin{abstract}
Several shallow lakes have been drained to make way for additional arable land or pasture in the Mazurian Lakeland (NE Poland) since the $19^{\text {th }}$ century. As a result of these hydrotechnical works, the water level usually decreased by approximately $6 \mathrm{~m}$. Bottom sediments of the former lakes were transformed into surface limnic soils. Part of them, developed from highly calcareous gyttja, may be called limnic rendzinas. However, the present position of these soils in the Polish Soil Classification is unclear. Where the lake has undergone a natural terrestrialisation, the gyttja is covered with peat and mursh. The raw gyttja soils differ in type of organic matter forming the topsoil horizon and are subject to further transformation, the direction of which depends on the sequence of sediments in the profile, mursh formation, mineral admixture and adjoining colluvial phenomena. Common features of all these soils are high content of calcium carbonate in the surface horizons, alkaline reaction, high groundwater level and periodical flooding. The paper presents the variability of limnic rendzinas based on many examples from the Mazurian Lakeland (NE Poland). Finally, new type additions were suggested to the next edition of the Polish Soil Classification.
\end{abstract}

Keywords: gyttja, calcareous gyttja, limnic rendzina, Mazurian Lakeland

\section{INTRODUCTION}

Limnic rendzinas are soils developed from highly calcareous limnic sediments. Hjalmar Uggla, the precursor of the research on such soils in Poland, called them Quaternary rendzinas (Uggla 1971, 1976). The investigations of these soils began during the documentation of the chalk deposits exploitation conducted in the Mazurian Lakeland since 1951. From that moment, interest in limnic rendzinas, also in other regions of Poland, has been growing. The majority of the research was conducted on organogenic-calcareous, peat-mursh soils covering calcareous gyttja (Olkowski 1967, 1971a, 1971b, Marcinek and Spychalski 1976, 1998, Krzywonos 1992, 1993, Meller 2004, 2006, Chmieleski 2006; Sowiński and Lemkowska 2010, Jarnuszewski 2015, 2016). Limnic rendzinas without the murshic horizon in the uppermost part of the profile are relatively rare and information on them is scarce (Uggla 1956, 1964, 1969, 1971, 1976, Zawadzki 1957, Prusinkiewicz and Noryśkiewicz 1975, Konecka-Betley and Stefaniak 1983, Lemkowska and Sowiński 2008, 2009).

The parent material for limnic rendzinas has developed in the shallow water bodies as a result of biochemical precipitation of $\mathrm{CaCO}_{3}$ supported by stoneworts (Chara sp.), pondweed (Najas marina), other plant species and a contribution of phytoplankton (Stasiak 1963, 1971, Rzepecki 1983, 1985, Sta- bel 1986, Dean and Fouch 1985, Dean 1999, Freytet and Verrecchia 2002, Schnurrenberger et al. 2003, Więckowski 2009, Alonso-Zarza and Wright 2010, Gierlowski-Kordesch 2010). Limnic sediments containing more than $20 \% \mathrm{CaCO}_{3}$ are described as calcareous gyttjas (marls), and more than $80 \% \mathrm{CaCO}_{3}$ as lacustrine chalk (Markowski 1971, 1980, Rzepecki 1983, Więckowski 2009). Depending on the location, lacustrine and palustrine facies are distinguished (Treese and Wilkinson 1982, Freytet and Verrecchia 2002, Schnurrenberger et. al 2003). The rate of sedimentation of carbonate gyttja averages from 0.4 to $2.0 \mathrm{~mm}$ per year with a maximum of $5 \mathrm{~mm}$ per year (Stasiak 1963, 1971). In the Mazurian Lakeland, accumulation of carbonates was the fastest in the second half of the warm Atlantic period (8000-5000 BP) (Stasiak 1963). High potential for the development of limnic rendzinas is guaranteed by deep deposits of calcareous gyttjas usually present in flow-through lakes (Rzepecki 1985, Petelski and Sadurski 1987) or in the lakes originally working as clarifiers for rivers (Więckowski 1993). The thickness of carbonate sediments in lakes may reach $5-10 \mathrm{~m}$ with a maximum of 25 m (Więckowski 1993). In the Mazurian Lakeland macroregion, the highest thickness of calcareous gyttja was observed in the Olsztyn Lakeland mesoregion, where it reaches $13.9 \mathrm{~m}$ in a "pure" calcareous gyttja and $12 \mathrm{~m}$ under the fen cover. In the deposits underlying peats in the other mesoregions, 
the maximum thickness amounts to $10.6 \mathrm{~m}$ in the Mragowo Lakeland, $10.0 \mathrm{~m}$ in the Mazurian Plain, $9.5 \mathrm{~m}$ in the Great Mazurian Lakes Region, $8.2 \mathrm{~m}$ in the Ełk Lakeland, $7.3 \mathrm{~m}$ in the Szeskie Hills and $5.9 \mathrm{~m}$ in the Wegorapa Region. The average thickness of calcareous gyttja underlying peats amounts to $2 \mathrm{~m}$.

The primary component of calcareous gyttja is fine crystalline calcite (size of crystals $<1 \mu \mathrm{m}$ ), which forms the aggregates $\phi<0.02 \mathrm{~mm}$ giving the silt-size pseudogranular structure of gyttja (Rutkowski 2007). It is modified by the allogenic components, such as grains of quartz, feldspars, and clay minerals, as well as autogenic vivianite, gypsum, iron sulphates, hydrated iron oxides and halite. Calcareous gyttja also contains diatoms. Phytoclasts and zooclasts are organic component of the sediments (Wyrwicki 2001, 2003).

The variability of limnic rendzinas is related to the process of terrestrialisation of lakes, which may be a natural or anthropogenic process. The first is natural deposition of gyttjas in the water body nearly filling the lake basin, then encroachment of peatforming vegetation and accumulation of peat until the lowering of the water level. In the latter phase, the peatland is excessively drained, which leads to its recession and transformation of the peat soils into the murshic ones. The other terrestrialisation process has a similar initial phase (sedimentation of the gyttja in a lake) however it is arrested anthropogenically (by hydrotechnical works and lake basin drainage) before the development of peat-forming vegetation. Therefore the gyttja exposed at the surface has no peat cover. In both cases, the objective of humans was to obtain additional space for grasslands or farming. The investigations on the substrate of fens conducted in the Mazurian Lakeland (Piaścik and Lemkowska 2004, Lemkowska and Piaścik 2006, Lemkowska et al. 2013, Lemkowska 2015, 2016) suggest that nearly 34000 ha of fens is underlaid by calcareous gyttja. It is the most abundant in the Great Mazurian Lakes Region (approximately 13000 ha), in the Mazurian Plain (7300 ha) and in the Olsztyn Lakeland (7200 ha). Considering the ongoing process of peat decomposition leading to the loss of organic matter, thinning of the organic layer and its mixing with the carbonate subsoil, a perspective for the development of limnic rendzinas emerges, changing the mosaic of soils in the post-glacial landscape. The objective of the paper was to present the variability of soil profiles and basic properties of limnic rendzinas of the Mazurian Lakeland.

\section{STUDY AREA AND METHODS}

The research was conducted in the Mazurian Lakeland (NE Poland), which was an area covered by an ice sheet during the last glacial period (Vistula glaciation). The following sites were studied: Peglity, Jęcznik, Kruklin, Malinowo, Wynki, and Ustnik.

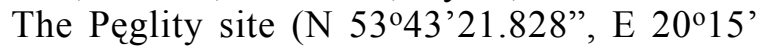
35.521 " - WGS 84 coordinates) is located in the Olsztyn Lakeland in the moraine landscape of the Pomeranian phase of the Vistula glaciation. The limnic soils developed after the water level fell in the Giłwa-Wulpińskie channel lakes complex connected and drained by the Giławka River. The hydrotechnical works were performed at the turn of the $19^{\text {th }}$ and $20^{\text {th }}$ century to obtain new meadow and pasture land (Piaścik and Lemkowska 2004, Skwierawski 2011). The calcareous gyttja soils in the western part of the former lake (105.0-110.0 $\mathrm{m}$ a.s.l.) are under agricultural use (profiles Pęglity 2-16), whereas a shallow fish pond still exists in the eastern part. In the area where the lacustrine chalk was the thickest (approximately $10 \mathrm{~m}$ ), it was exploited, which resulted in the development of an artificial lake (110 m a.s.l.) with a shore zone subject to rewetting (profile Pęglity 1) (53⒋ 18.943 ", E $20^{\circ} 18^{\prime} 41.281$ "). The former lake is surrounded by moraine hills (altitude up to $135 \mathrm{~m}$ a.s.1.) covered with brown soils (Cambisols), pararendzinas (Calcisols, Calcaric Regosols) and colluvial soils (mostly Phaeozems) in the contact zone (Lemkowska and Sowiński 2008).

The Jęcznik site $\left(53^{\circ} 21^{\prime} 55.062^{\prime \prime}\right.$, E $20^{\circ} 31^{\prime}$ 56.362 ") is located at the boundary of the Olsztyn Lakeland, the Mragowo Lakeland and the Mazurian Plain in the contact zone of the lakeland and outwash plain. The study area is former Lake Grom drained by the Jęcznik channel (137.1-137.4 $\mathrm{m}$ a.s.1.). The soils formed from the lake sediments are used as pasture (partly they are arable land). The direct vicinity of the channel is covered with a sedge community (fallow land) and the peripheries (profile Jęcznik 20) are occupied by recently planted forest. The surrounding moraine hills (altitude up to $154 \mathrm{~m}$ a.s.1.) are covered with brown soils (Cambisols) developed from sands and loams.

The Kruklin site (5401'40.451", E 21 '53'48.317') is located in the Great Mazurian Lakes Region at Lake Kruklin. This kettle lake existed in a separation until the water level decrease by $6.3 \mathrm{~m}$ between 1841 and 1851 and connecting it with the Lake Gołdapiwo by a channel in 1854 (Stasiak 1963). As a consequence of hydrotechnical works, the lacustrine chalk was exposed and exploited until the end of the $20^{\text {th }}$ century. In the 1990's, 90 ha from 260.6 ha described in geolo- 
gical documentation were exploited. The remaining 170.6 ha did not meet the technological criteria for exploitation. Initially, limnic rendzinas occurred here (as deducted from the geological documentation) with initial humus horizon or thin murshic horizon $(0.4 \mathrm{~m})$ covering the lacustrine chalk more than 4 m thick underlaid by clay. The area was transformed as a result of chalk mining; i.e. the excavation pits were reclaimed into ponds and arable land was recovered in dry terrain. In the area where exploitation was not conducted, limnic chernozemic rendzina are encountered (profiles 21, 22, 23) and used as meadows or arable land for cultivation of wheat or rapeseed.

The Malinowo fen (5328'23.063", E 20²0' 54.992”) is located at the western boundary of the Olsztyn Lakeland in the flat Witramówka valley connected with Lake Borówka. It is surrounded by terminal moraine hills (172.5-198 m a.s.1.) covered with loamy and sandy brown soils (Cambisols). In the study area of approximately 100 ha, exploitation of lacustrine chalk was conducted in an area of 29 ha. Before exploitation, limnic rendzinas had $\sim 30 \mathrm{~cm}$ thick humus horizons and also the murshic horizons of up to $70 \mathrm{~cm}$ thick were noted. They were underlain by calcareous gyttja with average thickness of $4.9 \mathrm{~m}$ (maximum thickness of $7.5 \mathrm{~m}$ ) deposited on sands. The presented profiles Malinowo 27, 28, 29 are located in the direct vicinity of the ponds remaining after the lacustrine chalk exploitation.

The Wynki wetland (5327'44.388', E2003' 16.812”) is located in the Olsztyn Lakeland at Lake Loby. The study area (18 ha) is a part of drained peatland transformed into pasture (currently rewetting fallows). It occupies a depression ( $95 \mathrm{~m}$ a.s.l.) drained by a channel connecting Lake Łoby with Lake Morag. Peat-mursh layers (0.2-2.1 m thick) are deposited on the calcareous gyttja (0.5-5.4 m thick). The neighbouring hills (99.0$116.9 \mathrm{~m}$ a.s.l.) are covered with Arenosols developed from outwash sands.

The Ustnik site (53059'39.507', E 2041' 53.498') is located in the Olsztyn Lakeland in a depression at an altitude of approximately $108 \mathrm{~m}$ a.s. 1 . Between the loamy-sandy hills of dead ice moraines (120-130 $m$ a.s.l.) a flow-through lake was located and drained to obtain land for grasslands. Due to the faulty draining system, a shallow $(0.5 \mathrm{~m})$ pond has developed on an area of 25.6 ha (Lemkowska et al. 2010). The soils developed from the calcareous limnic deposits were locally recorded in its vicinity (profile 30 ).

30 soil profiles and cores were performed in total in the sites mentioned above. The morphology of the profiles and their basic parameters are presented in Table and Figure. In the sampled material, the following properties were determined: loss on ignition in a muffle furnace at a temperature of $550^{\circ} \mathrm{C}$, the content of calcium carbonate (equivalent) by Scheibler volumetric method, soil $\mathrm{pH}$ by the potentiometric method in $1 \mathrm{~mol} \cdot \mathrm{dm}^{-3} \mathrm{KCl}$ and in distilled $\mathrm{H}_{2} \mathrm{O}$. The content of mineral non-carbonate fractions (MNCF) was calculated based on loss on ignition and the content of calcium carbonate. Soil colour was determined according to Munsell color charts (moist and dry). The soils were classified according to the Polish Soil Classification, $5^{\text {th }}$ edition (PSC 2011), World Reference Base for Soil Resources (IUSS Working Group WRB 2015). The proposal of soil types and subtypes for the $6^{\text {th }}$ edition of the Polish Soil Classification (planned in 2019) (website 1:) was also provided.

\section{RESULTS AND DISCUSSION}

Soils in the Peglity site were used as arable land (profile 2-8, 12-16) or extensive meadow (profiles 9,10 , and 14), excluding the places subject to rewetting (profile 1). On the soil-agricultural map, the soils of the area were considered black earths (Phaeozems) and alluvial soils (Fluvisols). Topsoil layers of limnic rendzinas contained up to $76 \% \mathrm{CaCO}_{3}$ and the lacustrine chalk in subsoil contained up to $91 \% \mathrm{CaCO}_{3}$. Carbonate deposits reached a depth of $6.8 \mathrm{~m}$. Due to the tendency for lumping of calcite grains to a size of $<0.02 \mathrm{~mm}$, the formation in horizons ALm and Lm resembles almost white silt when dry. Calcareous gleysols (gleby gruntowo-glejowe węglanowe) in profiles 10 and 16 are characterised by the lowest content of $\mathrm{CaCO}_{3}$ in topsoil layers due to colluvium supplied from the slope.

Soils in the Jęcznik fen were used as meadows and arable land. Currently, a major part of the area is occupied by grasslands (profiles 17 and 18) or fallows (profile 19). A forest was planted on the peripheries of the depression (profile 20). The sequence of horizons in the soil profiles suggests considerable water level fluctuations alternately transforming the limnic into a telmatic habitat. Cores have evidenced up to $9.5 \mathrm{~m}$ of calcareous gyttja deposited on the sandy bedrock. The decreasing water level resulted in the accumulation of sedge and alder-birch peat with a total thickness of approximately $70 \mathrm{~cm}$. The water level then increased again, which allowed an accumulation of the calcareous gyttja (approximately $62 \mathrm{~cm}$ ). Then the lake was drained to transform its bottom into grasslands. Therefore, the surface horizon ALm is developed from carbonate sediment with an extremely high content of $\mathrm{CaCO}_{3}(80 \%)$. The development of carbonate deposits suggests high abundance of $\mathrm{CaCO}_{3}$ in the geological materials of the catchment and an ongoing process of decalcification. The morphometric 
parameters of the shallow flow-through water body and biophysical conditions evidently contributed to the redeposition of carbonates in the water body. The calcareous gyttja deposited at the depth below 150 $\mathrm{cm}$ provide a reserve of parent material of limnic rendzinas.

The fen meadow Malinowo is covered with limnic chernozemic rendzinas (rędziny czarnoziemne pojeziorne) developed in course of natural terrestrialisation of the lake (profiles 27, 28, and 29). Topsoil horizon MLm has developed as a result of anthropogenic mixing of the murshic horizon with the carbonate substrate (calcareous-shell gyttja), evidenced by high content of calcium carbonates $(50-73 \%)$ and the presence of shells. The presence of conchiolins in horizon $\mathrm{Lm}$ simulates a paraskeleton resulting in a specific coarse detritus structure. The groundwater table was measured at a depth of $63-73 \mathrm{~cm}$ increasing periodically towards the surface.

The Wynki fen (profiles 24, 25, and 26) was used as a pasture in the past and is currently under rewetting. The water level is maintained on the surface for a major part of the year. In the summer, it decreases to $50 \mathrm{~cm}$ below ground level, where Limnic chernozemic rendzinas (rędziny czarnoziemne pojeziorne) occur. Peat mursh in the profiles 25 and 26 is enriched with calcium carbonate $(22 \%)$. In profile 24 , horizon MLm has a gyttja character, therefore the content of $\mathrm{CaCO}_{3}$ is twice as high. Horizon Lm is developed from calcareous gyttja with greyish-orange colour.

A consequence of draining water from lakes in the Mazurian Lakeland is remodelling of the land relief. As a result of the transformation, the shore of the lake formerly located at the lowest position in the local relief currently towers over the surroundings and the differences reach several meters. Mineral materials usually originating directly from the neighbouring slopes cover the calcareous layers and the soils are included into brown soils (Cambisols) or Gleysols in the soil maps. An example is calcareous gleysol (gleba gruntowo-glejowa weglanowa) represented by profile 30 (Ustnik area), located in the prelittoral zone (115 $\mathrm{m}$ a.s.l.). Soil originating from sandy loam deposited on calcareous gyttja with a $60 \%$ of $\mathrm{CaCO}_{3}$ has developed as a result of formation of agricultural colluvium supported by human activity. Sandy loam horizon Gca is compact and partly cemented.

Draining of the shallow lakes caused exposure of bottom sediments and transformation of the subhydric into the terrestrial sediments. Due to the specific development of gyttja depending on the character of the water body, its size, depth, shape, form, alimentation, and biotic and abiotic factors, the spatial variability of sediments, being the parent material for limnic soils, show certain patterns in the soil catena. In the littoral zone of the former lake, where the original water was shallower and the facility of precipitation of $\mathrm{CaCO}_{3}$ the highest, the sediments with an average thickness of 2-4 m and maximum $\mathrm{CaCO}_{3}$ content of up to $95 \%$ are encountered (Rutkowski 2007). These sediments are enriched with plant remains. Gyttja is white, white-yellow, or light grey in colour and does not show lamination. The degree of aggregation of calcium carbonate makes it similar to silt or clay texture. Locally in this zone, conchiolins of molluses developed a shell bar (necrocoenosis) (Malinowo 27, 28, 29, Kruklin 21, 22) suggesting shallow water (Stasiak 1963, Rutkowski 2007, Alexandrowicz 2007). Due to ploughing of the topsoil layer, the shells are visible on the soil surface (Kruklin, Malinowo). Fragments of shells $>2.0 \mathrm{~mm}$ in diameter provide a specific coarse fraction to the limnic soil also giving an additional source/reserve of calcium carbonate (although less reactive than chemically precipitated $\mathrm{CaCO}_{3}$ ). Towards the palaeoprofundal zone, calcareous gyttjas reach a thickness of $10 \mathrm{~m}$, are laminated and less enriched in $\mathrm{CaCO}_{3}(50-80 \%)$. They are usually light or dark grey in colour, sometimes pink (Wynki 24) or red shade due to the presence of carotenes, green due to chlorophyll, or brown due to humus compounds. According to some authors, they are sometimes black from hydrotroilite $\left(\mathrm{FeS} \cdot \mathrm{nH}_{2} \mathrm{O}\right)$ (Rzepecki 1985, Więckowski 1993, 2009).

The presented soils have many similar features due to the properties provided by a high calcium carbonate content. Calcareous gyttja is a specific parent material with properties changing with its moisture. The state of granulation simulates the loamy, silt loamy, silty or clayey textures. In the dry state in the topsoil horizon, it has a granular structure with a substantial contribution of organic parts - fine platy, shard, but with an increase in moisture, it becomes sticky and plastic, which is related to $\mathrm{CaCO}_{3}$ taking gel consistence. This causes a swelling of gyttjas and makes it waterproof (Dobak and Wyrwicki 2000, Wyrwicki 2001). Due to the hydrological conditions, the soils under study are subject to the groundwater and flood impacts regularly or for a major part of the year. In the case of a decrease in the water level and drying, the soil becomes more porous due to shrinking and fissure formation. This is reflected in variable air-water and temperature conditions. The amplitude of water level fluctuations in the gyttja soils provides extremely specific conditions for plant growth. This eliminates some crops and is responsible for the low compactness of sward (Olkowski 1971b). Grasslands are low quality for agriculture and are evaluated as the $\mathrm{V}$ class of bonitation according to 


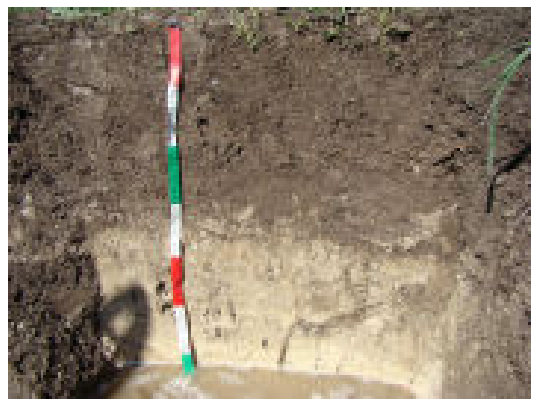

a

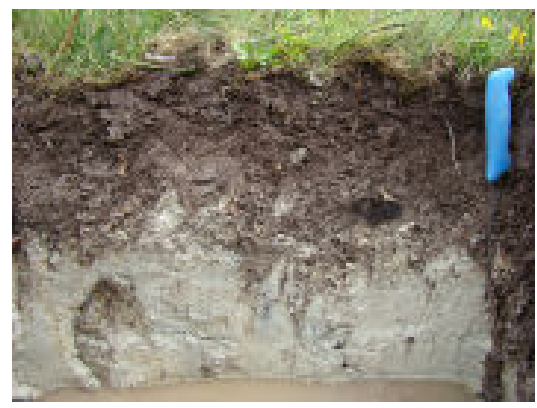

d

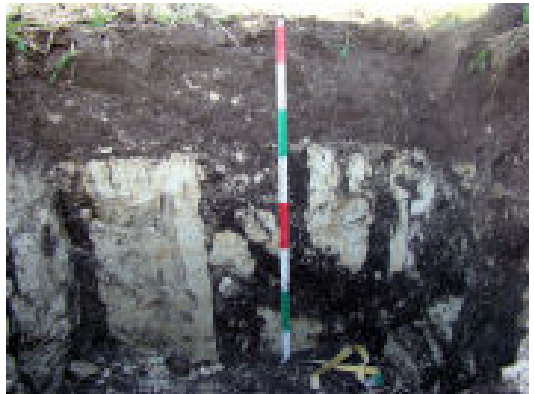

b

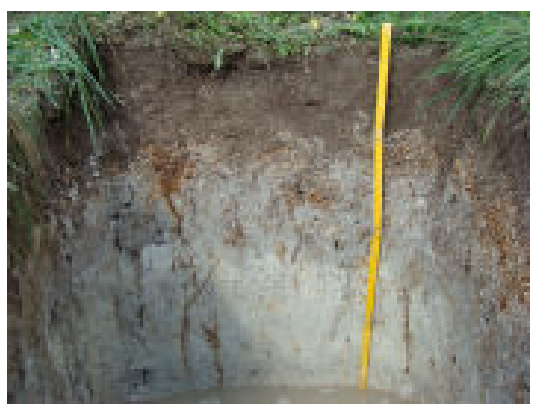

e

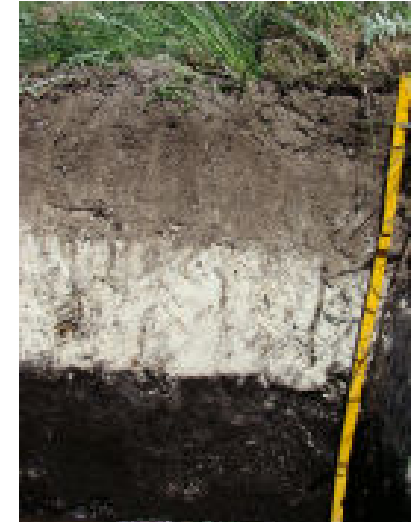

$\mathrm{h}$

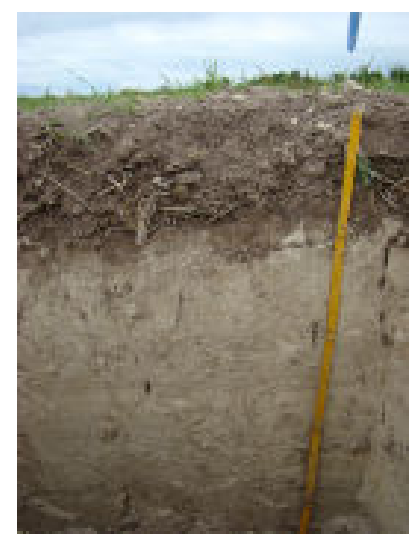

$\mathrm{k}$

i

1

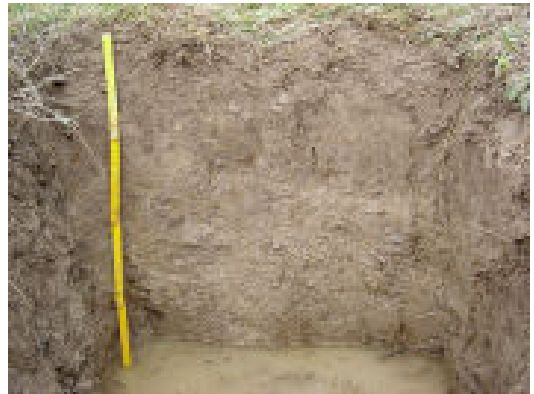

c

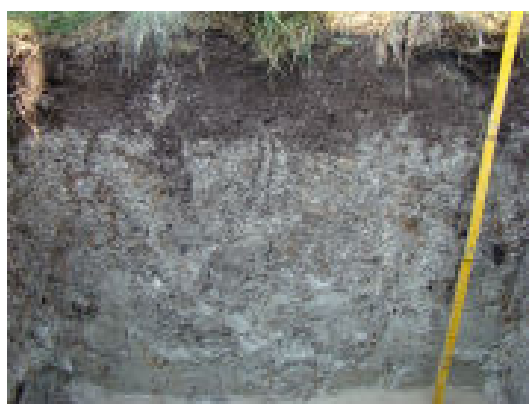

f
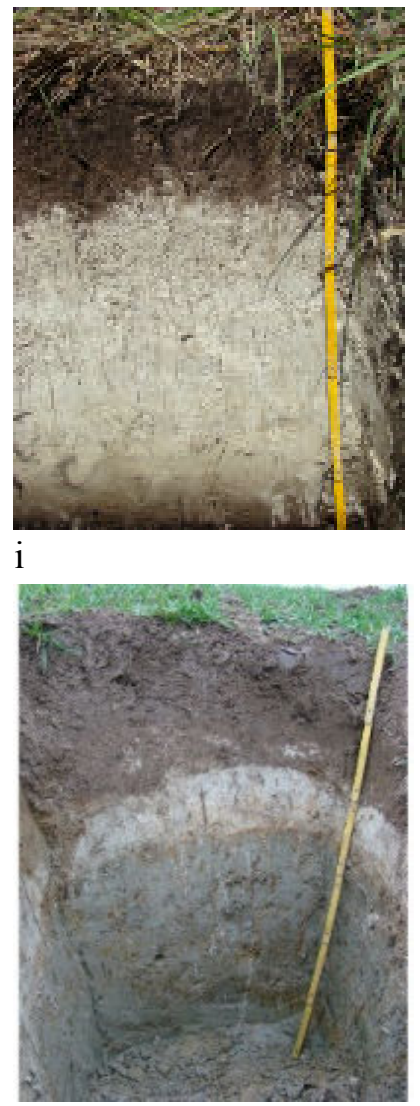

FIGURE. The morphology of limnic rendzinas from the Mazurian Lakeland. Profiles: a - Pęglity 4, b - Peglity 7, c - Pęglity 9 , d - Wynki 24, e- Malinowo 28, f - Malinowo 29, g - Jęcznik 17, h - Jęcznik 18, i - Jęcznik 19, j - Kruklin 21, k - Kruklin 23, 1 - Ustnik 30 
TABLE . Selected properties of limnic rendzinas from the Mazurian Lakeland: A - arable land, M - meadow, F - forest, $\mathrm{W}$ - wetland, LOI - loss on ignition, MNCF - mineral, non-carbonate fractions, PSC - Polish soils classification (PSC 2011), * ground water level, ${ }^{* *}$ according to PSC 2011, ${ }^{* * *}$ according to WRB 2015, • proposition to PSC 2019 (website 1)

\begin{tabular}{|c|c|c|c|c|c|c|c|c|c|c|c|}
\hline & \multirow[t]{2}{*}{ Profile } & \multirow{2}{*}{$\begin{array}{l}\text { No } \\
\text { /land us }\end{array}$} & Horizon & Depth & LOI & $\mathrm{CaCO}_{3}$ & $\mathrm{MNCF}$ & $\mathrm{pH}$ & \multicolumn{3}{|c|}{ Munsell Color } \\
\hline & & & symbol & $(\mathrm{cm})$ & $(\%)$ & & & $\mathrm{H}_{2} \mathrm{O}$ & $\mathrm{KCl}$ & moist & dry \\
\hline \multicolumn{12}{|c|}{ Pęglity } \\
\hline & $\mathrm{W}$ & 1 & \multicolumn{9}{|c|}{$\begin{array}{l}\text { Calcareous gleysol (gleba gruntowo-glejowa węglanowa) / Typical gleysol (gleba glejowa typowa)** / } \\
\text { Calcaric Gleysols (Limnic)*** }\end{array}$} \\
\hline & & & $\mathrm{Lcm}$ & $0-26$ & 10.3 & 21.7 & 68.0 & 8.0 & 7.4 & $10 \mathrm{YR} 4 / 2$ & $10 \mathrm{YR} 5 / 2$ \\
\hline & & & $\mathrm{Lm}$ & $26-62 *-150$ & 9.7 & 86.4 & 3.9 & 8.2 & 8.0 & $2.5 Y 7 / 3$ & 10YR $8 / 1$ \\
\hline & A & 2 & \multicolumn{9}{|c|}{$\begin{array}{l}\text { Limnic chernozemic rendzina (rędzina czarnoziemna pojeziorna) / Typical black earth } \\
\text { (czarna ziemia typowa)** / Rendzic Phaeozems*** }\end{array}$} \\
\hline & & & ALm & $0-30$ & 15.1 & 54.7 & 30.2 & 7.9 & 7.4 & $2.5 Y 5 / 3$ & $2.5 \mathrm{Y} 7 / 2$ \\
\hline & & & $\mathrm{Lml}$ & $30-100$ & 13.2 & 83.0 & 3.7 & 8.2 & 7.9 & $2.5 \mathrm{Y} 8 / 3$ & $2.5 \mathrm{Y} 8 / 2$ \\
\hline & & & $\mathrm{Lm} 2$ & $100-126 *-150$ & 14.1 & 45.7 & 40.2 & 8.1 & 7.7 & $2.5 Y 5 / 3$ & $2.5 \mathrm{Y} 7 / 2$ \\
\hline & A & 3 & \multicolumn{9}{|c|}{$\begin{array}{l}\text { Limnic chernozemic rendzina (rędzina czarnoziemna pojeziorna) } \downarrow / \text { Typical black earth } \\
\text { (czarna ziemia typowa)** / Rendzic Phaeozems*** }\end{array}$} \\
\hline & & & ALm & $0-26$ & 15.3 & 58.8 & 25.9 & 7.9 & 7.4 & 10 YR $5 / 3$ & $2.5 Y 7 / 1$ \\
\hline & & & $\mathrm{Lm}$ & $26-78^{*}$ & 13.3 & 81.3 & 5.4 & 8.2 & 7.9 & $2.5 \mathrm{Y} 8 / 3$ & $2.5 \mathrm{Y} 8 / 2$ \\
\hline & A & 4 & \multicolumn{9}{|c|}{$\begin{array}{l}\text { Calcareous gleysol (gleba gruntowo-glejowa węglano)w / Typical gleysol } \\
\text { (gleba glejowa typowa) }{ }^{* *} \text { Calcaric Gleysols (Limnic)** / }\end{array}$} \\
\hline & & & ALm & $0-33$ & 18.6 & 32.6 & 48.8 & 7.8 & 7.4 & $2.5 \mathrm{Y} 4 / 2$ & $2.5 \mathrm{Y} 6 / 2$ \\
\hline & & & $\mathrm{Lm}$ & $33-62 *$ & 16.8 & 75.4 & 7.8 & 8.2 & 7.9 & $25 \mathrm{Y} 8 / 3$ & $2.5 \mathrm{Y} 8 / 2$ \\
\hline & A & 5 & \multicolumn{9}{|c|}{$\begin{array}{l}\text { Limnic chernozemic rendzina (rędzina czarnoziemna pojeziorna) } \downarrow / \text { Typical black earth } \\
\text { (czarna ziemia typowa)** / Rendzic Phaeozems*** }\end{array}$} \\
\hline & & & ALm & $0-20$ & 13.5 & 61.6 & 25.0 & 7.9 & 7.5 & $10 Y R 5 / 2$ & 10YR 7/1 \\
\hline & & & $\mathrm{Lm}$ & $20-67 *$ & 10.2 & 87.2 & 2.5 & 8.4 & 8.1 & $2.5 \mathrm{Y} 8 / 2$ & $5 Y 8 / 1$ \\
\hline & A & 6 & \multicolumn{9}{|c|}{$\begin{array}{l}\text { Limnic chernozemic rendzina (rędzina czarnoziemna pojeziorna) } \\
\text { (czarna ziemia typowa)** / Rendzic Phaeozems black earth }\end{array}$} \\
\hline & & & ALm & $0-30$ & 21.9 & 55.4 & 22.8 & 7.9 & 7.5 & 10YR 5/2 & 10YR 7/1 \\
\hline & & & $\mathrm{Lm}$ & $30-54 *$ & 10.3 & 84.3 & 5.4 & 8.4 & 8.0 & $2.5 \mathrm{Y} 8 / 2$ & $5 Y 8 / 1$ \\
\hline & A & 7 & \multicolumn{9}{|c|}{$\begin{array}{l}\text { Limnic chernozemic rendzina (rędzina czarnoziemna pojeziorna) }-/ \text { Typical black earth } \\
\text { (czarna ziemia typowa)** / Rendzic Phaeozems*** }\end{array}$} \\
\hline & & & ALm & $0-30$ & 24.9 & 49.3 & 25.8 & 8.0 & 7.7 & 10 YR $5 / 2$ & 10YR 7/1 \\
\hline & & & $\mathrm{Lm}$ & $30-102 *$ & 10.4 & 88.1 & 1.5 & 8.4 & 8.0 & $2.5 \mathrm{Y} 8 / 2$ & $5 Y 8 / 1$ \\
\hline & A & 8 & \multicolumn{9}{|c|}{$\begin{array}{l}\text { Limnic chernozemic rendzina (rędzina czarnoziemna pojeziorna) } \\
\text { (czarna ziemia typowa)** / Rendzic Phaeozems*** black earth }\end{array}$} \\
\hline & & & ALm & $0-36$ & 16.3 & 59.0 & 24.7 & 7.8 & 7.4 & 10 YR $5 / 3$ & 10YR $7 / 2$ \\
\hline & & & $\mathrm{Lm}$ & $36-53 *$ & 10.4 & 72.5 & 17.1 & 8.3 & 7.9 & $2.5 \mathrm{Y} 8 / 2$ & $5 Y 8 / 1$ \\
\hline & M & 9 & \multicolumn{9}{|c|}{$\begin{array}{l}\text { Calcareous gleysol (gleba gruntowo-glejowa węglanowa) } \bullet \text { Typical gleysol (gleba glejowa typowa)** } \\
\text { /Calcaric Gleysol s (Limnic)*** }\end{array}$} \\
\hline & & & (A) $\mathrm{Lm}$ & $0-35$ & 11 & 73.4 & 15.5 & 7.6 & 7.1 & 10YR 6/2 & 10YR 8/1 \\
\hline & & & $\mathrm{Lm}$ & $35-54 *-150$ & 7.5 & 59.3 & 33.2 & 8.1 & 7.3 & $2.5 \mathrm{Y} 6 / 3$ & $2.5 \mathrm{Y} 8 / 1$ \\
\hline & M & 10 & \multicolumn{9}{|c|}{$\begin{array}{l}\text { Calcareous gleysol (gleba gruntowo-glejowa węglanowa) } \\
\text { /Calcaric Gleysols (Limnic)*** Typal gleysol (gleba glejowa typowa)** }\end{array}$} \\
\hline & & & ALm & $0-25$ & 18.9 & 19.4 & 61.7 & 7.7 & 7.2 & 10 YR $3 / 3$ & $10 \mathrm{YR} 4 / 2$ \\
\hline & & & $\mathrm{Lm}$ & $25-55$ & 13.8 & 48.6 & 37.6 & 8.0 & 7.4 & 10YR 4/2 & $10 \mathrm{YR} 7 / 2$ \\
\hline & & & $\mathrm{Lcm}$ & $55-100 *-150$ & 25.4 & 20.0 & 54.6 & 7.8 & 7.3 & 10 YR $3 / 3$ & $10 \mathrm{YR} 5 / 2$ \\
\hline
\end{tabular}


TABLE continued

\begin{tabular}{|c|c|c|c|c|c|c|c|c|c|c|c|}
\hline & \multirow[t]{2}{*}{ Profile } & \multirow{2}{*}{$\begin{array}{l}\text { No } \\
\text { /land us }\end{array}$} & Horizon & Depth & LOI & $\mathrm{CaCO}_{3}$ & MNCF & $\mathrm{pH}$ & \multicolumn{3}{|c|}{ Munsell Color } \\
\hline & & & symbol & $(\mathrm{cm})$ & $(\%)$ & & & $\mathrm{H}_{2} \mathrm{O}$ & $\mathrm{KCl}$ & moist & dry \\
\hline \multicolumn{12}{|l|}{ Pęglity } \\
\hline & $\bar{A}$ & 11 & \multicolumn{9}{|c|}{$\begin{array}{l}\text { Calcareous gleysol (gleba gruntowo-glejowa węglanowa) } \bullet / \text { Gleyic black earth (czarna ziemia glejowa)** / } \\
\text { Calcaric Gleysols (Limnic)*** }\end{array}$} \\
\hline & & & ALm & $0-13$ & 13.9 & 76.1 & 10.0 & 8.0 & 7.6 & $2.5 \mathrm{Y} 5 / 3$ & 10YR 7/1 \\
\hline & & & $\underline{\mathrm{Lm} 1}$ & $13-22$ & 12.6 & 78.3 & 9.1 & 8.0 & 7.6 & 10YR 5/2 & 10YR 7/1 \\
\hline & & & $\mathrm{Lm} 2$ & $22-28 *$ & 10.5 & 81.0 & 8.5 & 8.4 & 8.1 & $2.5 \mathrm{Y} 7 / 2$ & 10YR 8/1 \\
\hline & A & 12 & \multicolumn{9}{|c|}{$\begin{array}{l}\text { Calcareous gleysol (gleba gruntowo-glejowa węlanowa) } \bullet / \text { Gleyic black earth (czarna ziemia glejowa)** / } \\
\text { Calcaric Gleysol (Colluvic)*** }\end{array}$} \\
\hline & & & ALm & $0-26$ & 20.9 & 48.5 & 30.6 & 8.0 & 7.3 & 10YR 4.2 & 10YR 6/2 \\
\hline & & & Gca & $26-150$ & 9.7 & 9.0 & 81.4 & 8.3 & 7.3 & $2.5 \mathrm{Y} 5 / 3$ & $2.5 \mathrm{Y} 7 / 2$ \\
\hline & A & 13 & \multicolumn{9}{|c|}{$\begin{array}{l}\text { Limnic chernozemic rendzina (rędzina czarnoziemna pojeziorna) } \\
\text { (czarna ziemia typowa)** / Rendzic Phaeozems*** black earth }\end{array}$} \\
\hline & & & ALm & $0-30$ & 24.4 & 48.5 & 27.1 & 8.0 & 7.6 & $2.5 \mathrm{Y} 3 / 3$ & $2.5 \mathrm{Y} 6 / 2$ \\
\hline & & & $\mathrm{Lm}$ & $30-67^{*}$ & 8.7 & 90.2 & 1.1 & 8.4 & 8.2 & $2.5 \mathrm{Y} 8 / 2$ & 10YR 8/1 \\
\hline & M & 14 & \multicolumn{9}{|c|}{$\begin{array}{l}\text { Limnic chernozemic rendzina (rędzina czarnoziemna pojeziorna) ?/ Typical black earth } \\
\text { (czarna ziemia typowa)** / Rendzic Phaeozems*** }\end{array}$} \\
\hline & & & (A)Lm & $0-30$ & 23.8 & 55.7 & 20.5 & 7.8 & 7.6 & $2.5 Y 5 / 3$ & $2.5 Y 7.2$ \\
\hline & & & $\mathrm{Lm} 1$ & $30-45$ & 15.5 & 82.2 & 2.3 & 8.3 & 7.8 & $2.5 \mathrm{Y} 7 / 3$ & $2.5 \mathrm{Y} 8 / 2$ \\
\hline & & & $\mathrm{Lm} 2$ & 45-90* & 18.7 & 80.2 & 1.1 & 8.8 & 8.3 & $2.5 Y 2 / 1$ & $2.5 \mathrm{Y} 4 / 1$ \\
\hline & A & 15 & \multicolumn{9}{|c|}{$\begin{array}{l}\text { Limnic chernozemic rendzina (rędzina czarnoziemna pojeziorna) } \\
\text { (czarna ziemia typowa)** / Typical black earth }\end{array}$} \\
\hline & & & ALm & $0-30$ & 25.2 & 40.0 & 34.8 & 7.9 & 7.4 & $10 \mathrm{YR} 3 / 3$ & $2.5 \mathrm{Y} 6 / 2$ \\
\hline & & & $\mathrm{Lm}$ & $30-57 *-150$ & 8.2 & 91.0 & 0.8 & 8.3 & 7.9 & 10 YR $8 / 3$ & $10 \operatorname{Yr} 8 / 1$ \\
\hline & A & 16 & \multicolumn{9}{|c|}{$\begin{array}{l}\text { Calcareous gleysol (gleba gruntowo-glejowa weglanowa) } \bullet / \text { Typical gleysol (gleba glejowa typowa)** } \\
\text { Calcaric Gleysols (Limnic)***/ }\end{array}$} \\
\hline & & & Aca & $0-30$ & 12.4 & 3.9 & 83.7 & 7.9 & 7.2 & 10YR 3/2 & $2.5 Y 5 / 3$ \\
\hline & & & $\mathrm{Lm}$ & $30-60$ & 10.2 & 81.3 & 8.5 & 8.3 & 7.9 & 10YR 7/3 & 10YR 8/1 \\
\hline & & & Gca & $60-150$ & 4.7 & 10.7 & 84.6 & 8.2 & 7.3 & $5 Y 5 / 3$ & $2.5 \mathrm{Y} 7 / 3$ \\
\hline \multicolumn{12}{|l|}{ Jęcznik } \\
\hline & M & 17 & \multicolumn{9}{|c|}{$\begin{array}{l}\text { Limnic calcareous soil (gleba oraganiczna limnowa weglanowa) } \bullet / \text { Calcareous limnic soil } \\
\text { (gleba organiczna węglanowo-limnowa)** / Drainic Histosols (Calcaric Limnic) })^{* * *}\end{array}$} \\
\hline & & & ALm & $0-21$ & 17.0 & 77.1 & 5.9 & 8.0 & 7.32 & 10YR 3.3 & 10YR 6.2 \\
\hline & & & $\mathrm{Lm} 1$ & $21-31$ & 8.8 & 86.4 & 4.8 & 8.0 & 7.63 & $7.5 \mathrm{Y} 8 / 3$ & 10YR 8/1 \\
\hline & & & $\mathrm{Oa}$ & $31-70$ & 73.8 & 3.8 & 22.5 & 7.8 & 7.4 & 7.5YR 2/2 & 10YR 2/2 \\
\hline & & & $\mathrm{Lm} 2$ & $70-72 *-150$ & 4.6 & 94.8 & 3.4 & 8.1 & 8.06 & 10 YR $8 / 3$ & 10YR 8/1 \\
\hline & M & 18 & \multicolumn{9}{|c|}{$\begin{array}{l}\text { Calcareous gleysol (gleba gruntowo-glejowa węglanowa) } \bullet / \text { Gleyic black earth (czarna ziemia glejowa)** / } \\
\text { Calcaric Gleysols (Limnic)*** }\end{array}$} \\
\hline & & & ALm & $0-23$ & 13.5 & 80.1 & 6.4 & 7.8 & 7.33 & 10YR 5/3 & 10YR 7/2 \\
\hline & & & $\mathrm{Lm}$ & $23-44$ & 4.0 & 95.2 & 0.8 & 8.0 & 8.01 & $2.5 \mathrm{Y} 8 / 2$ & 7.5YR 8/1 \\
\hline & & & $\mathrm{Oa}$ & $44-76^{*}-150$ & 82.3 & 0.3 & 17.4 & 7.7 & 7.15 & 10YR 1.7/1 & 10YR 2/1 \\
\hline & W & 19 & \multicolumn{9}{|c|}{$\begin{array}{l}\text { Limnic chernozemic rendzina (rędzina czarnoziemna pojeziorna) } \bullet / \text { Typical black earth } \\
\text { (czarna ziemia typowa)** / Rendzic Phaeozems*** }\end{array}$} \\
\hline & & & MLm & $0-26$ & 24.1 & 35.7 & 40.2 & 8.2 & 7.23 & $10 \mathrm{YR} 4 / 2$ & 10YR 5/2 \\
\hline & & & Lml & $26-74$ & 8.4 & 88.5 & 3.1 & 8.0 & 7.8 & $2.5 Y 7 / 2$ & 10YR 8/1 \\
\hline & & & $\mathrm{Lm} 2$ & $74-88$ & 13.0 & 77.5 & 9.4 & 8.3 & 8.16 & $2.5 Y 7 / 3$ & 10YR 8/1 \\
\hline & & & $\mathrm{Oa}$ & $88-123$ & 87.5 & 0.3 & 12.2 & 7.4 & 6.68 & 10YR 2/2 & 10YR 2/3 \\
\hline & & & $\mathrm{Lm3}$ & $123-93 *-150$ & 4.0 & 94.0 & 2.0 & 8.0 & 8.0 & $2.5 \mathrm{Y} 8 / 2$ & $7.5 Y 8.1$ \\
\hline & $\mathrm{F}$ & 20 & \multicolumn{9}{|c|}{$\begin{array}{l}\text { Limnic calcareous soil (gleba oraganiczna limnowa weglanowa) } \bullet / \text { Calcareous limnic soil } \\
\text { (gleba organiczna weglanowo-limnowa)** / Drainic Histosols (Calcaric Limnic)*** }\end{array}$} \\
\hline & & & MLm & $0-25$ & 20.4 & 61.1 & 18.5 & 7.4 & 7.12 & $10 \mathrm{YR} 4 / 2$ & 10YR 6/2 \\
\hline & & & $\mathrm{Lm}$ & $25-39$ & 6.4 & 84.3 & 9.3 & 8.0 & 7.66 & 10YR 8/3 & 10YR 8/1 \\
\hline & & & $\mathrm{Oa}$ & $39-150$ & 88.6 & 0.4 & 11.0 & 7.3 & 6.35 & 10YR 1.7/1 & 10YR 2/1 \\
\hline
\end{tabular}


TABLE continued

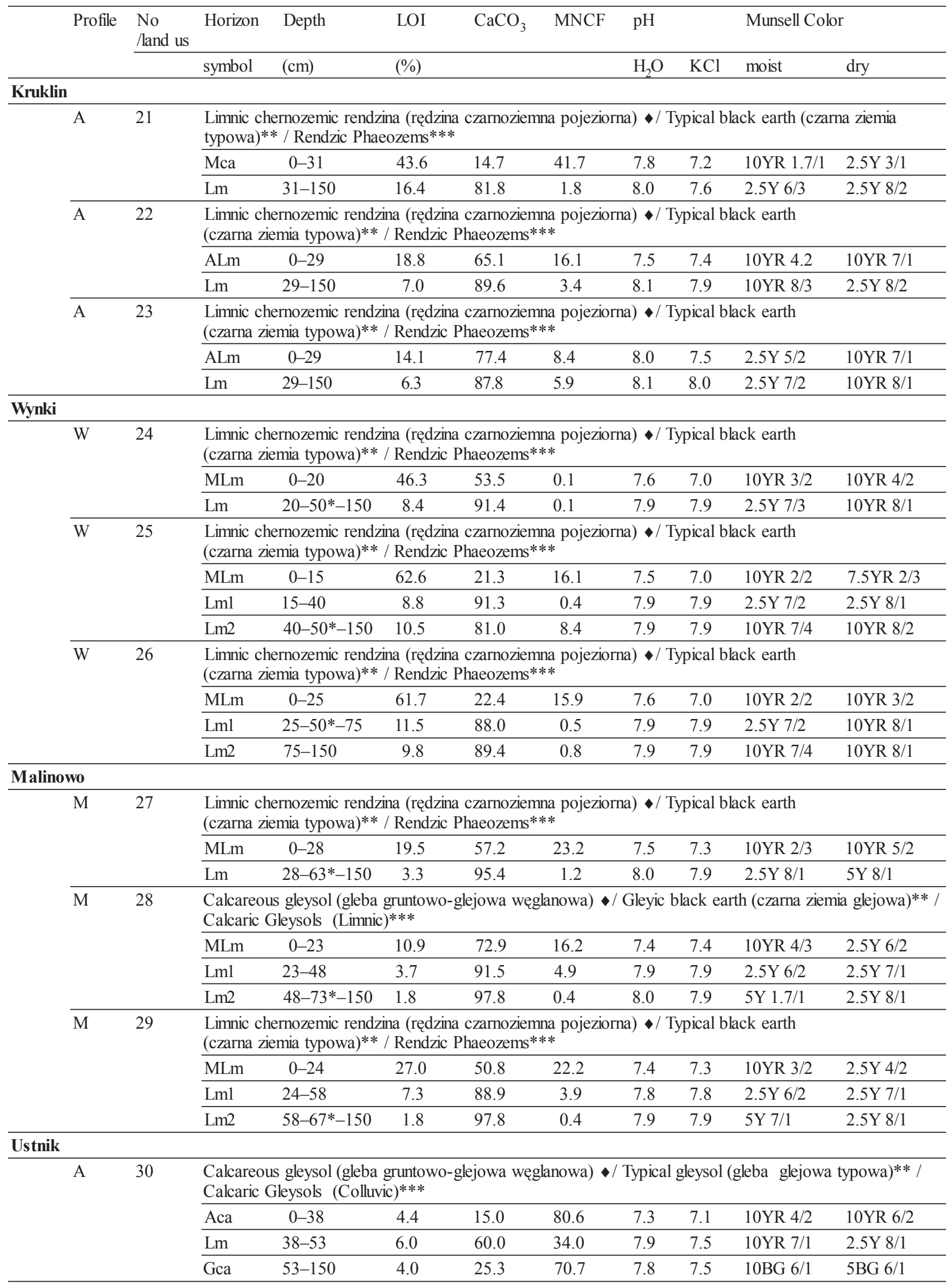


Polish rules. Attempts at grazing (Wynki 24, 25, 26, Malinowo 27, Jęcznik 19) were unsuccessful due to animals getting bogged down and destruction of the soil structure and turf. Due to the elimination of plants valuable for animals, the owners sometimes give up on using the soils.

High content of calcium carbonate maintains soil $\mathrm{pH}_{\mathrm{H} 2 \mathrm{O}}$ at a level of 7-8 throughout the profile. Due to the buffer ability and reactivity of Quaternary chalk, the alkaline reaction will be maintained for a long time. This leads to the immobilisation of nutrients, disturbance in the balance between macroelements, and immobilisation of microelements (Lemkowska and Sowiński 2009, Sowiński and Lemkowska 2010). Conditions unfavourable for the plant growth are magnified by oxygen deficiency caused by high water level. Under such conditions, geochemical transformations follow according to modified chemical trails (Kirk 2004). A disturbance in nutrition of plants results in a decrease in crop yields. Dehydration of organic soils developed on carbonate sediments leads to the long-lasting or permanent transformations. Mursh formation and increasing effect of the substrate stimulated by cultivation definitively transform the soil environment (Marcinek 1976a, 1976b, Marcinek and Spychalski 1976, 1998, Krzywonos 1992, 1993, Meller 2004, 2006, Jarnuszewski 2015, 2016). Loss of water causes shrinking of gyttja and irreversible changes in colloids (Żurek-Pysz 1992, 2001, 2007, Żurek-Pysz and Skalski 2003). Because unfavourable systems of hydraulic resistance develop in laminated formations after dehydration (Marcinek and Spychalski 1998), the mixing of chalk with the overlying sediments/materials can counteract this unfavourable phenomenon. The mixed horizon, however, may be a subject to rapid further transformations. Excess of active carbonates causes a decrease in the amount of humus compounds and deterioration of their quality through hindering polymerisation of multiparticle humus bindings (Kuźnicki and Skłodowski 1976, Kowaliński and Licznar 1986).

Because lacustrine chalk changes its physical and chemical properties under the pressure of the longterm application of heavy equipment for soil cultivation, the limnic rendzinas can experience unfavourable changes in the soil profiles. Kneading results in a decrease in porosity and development of microturbulent structure. Pores become filled with autigenic minerals, calcite grains become larger and aggregated with organic matter. Amorphous opal is also transformed into crystalline quartz, thus the sediment is subject to cementation (Żurek-Pysz 1998, 2003, De Boever et al. 2017). This can lead to the lithification of lacustrine chalk and changes of its properties. Symptoms of this negative phenomenon were observed in the areas of former exploitation of lacustrine chalk, where initial rendzinas with the contribution of xeromorphic vegetation are developed on compact carbonate substrate occurring on hills remaining after former chalk heaps. Cementation was also observed in Gca horizons, where the water table level considerably decreased (profiles 12, 16, 30).

Properties of organic soils underlaid with carbonate gyttja depend on the thickness of the organic layer of peat, mursh and type and intensity of land use. In the murshic soils on the non-carbonate substrate, the decalcification process occurs (Piaścik 1977), whereas soils underlaid with carbonate gyttja are enriched with calcium. Migration of $\mathrm{Ca}^{2+}$ ions, or entire $\mathrm{CaCO}_{3}$ particles to topsoil horizons occur with a contribution of increasing groundwater level. This is observed on the soil surface in the form of efflorescences (similarly as in saline soils). After thinning the organic layer and mixing it by ploughing with the carbonate subsoil, a rapid increase in the content of $\mathrm{CaCO}_{3}$ occurs in the surface horizon. With each ploughing, new parts of calcium carbonate in the form of blocks enrich the murshic horizon. The blocks are unstable and fall apart after rainfalls, resulting in a sludging of the soil surface. The mixing of the topsoil and subsoil layers is uneven. However, due to small size of calcite particles, as well as high reactivity of gyttja (compared to older calcareous rocks such as limestones or marls), $\mathrm{CaCO}_{3}$ is easily transported with water, fills pores, and reacts with the remaining soil components. The primary sequence of horizons disappears in the soil profile until the disappearance of carbonate gyttja mixed with the surface horizon (ALm or MLm). Alternating decrease and increase in the water table in gyttja layers may produce the deep crevices filled with surface material, and particularly mursh, due to the specific properties of carbonate sediments, in particular their shrinkage and swelling ability comparable with clay (Dobak and Wyrwicki 2000, Wyrwicki 2001) (Pęglity 7, 14, Wynki 25, Kruklin $21,22)$. The resulting wedges form a polygonal structure (Zawadzki 1957) similar to that described in peats (Frąckowiak and Feliński 1994), modifying the spatial variability of further water retention. These vertical channels develop a kind of ventilation duct with a draining function after the period of flooding and swelling of gyttja.

Due to the high content of $\mathrm{CaCO}_{3}$, organic matter is subject to rapid decomposition (Maciak and Liwski 1972) and mineralisation, and the carbonate substrate gains increasing importance. Due to this, the thickness of topsoil sediments is very important, because it determines the direction and rate of trans- 
formation, as well as the properties of the developing soils. The thinning rate of the organic soils as a result of peat decomposition averages $1 \mathrm{~cm}$ per year. It permits the forecasting of the scale of soil cover transformation in the post-lacustrine landscape over time. Considering the fast rate of transformations stimulated by calcium carbonate and aeration, it seems important to consider even thin layers abundant in $\mathrm{CaCO}_{3}$ present in the topsoil or subsoil. Calcium carbonate is a component with an almost $100 \%$ reactivity and it will be the primary soil buffer until its total exhaustion.

\section{SUMMARY AND CONCLUSIONS}

Limnic rendzinas in the Mazurian Lakeland developed as a result of terrestrialisation lakes, drainage of peatlands underlain with calcareous gyttja, or drainage of lakes and gyttja exposure at the land surface. The obtained space is used as arable land, meadows, pastures, and forests. However, difficulties in land use cause its abandonment and rewetting. The mineral admixtures, both due to alluvial and colluvial processes, contribute to a decrease in the content of calcium carbonate in the topsoil horizon, positively modifying properties of limnic rendzinas. The murshic process of peat soils underlaid with calcareous gyttja leads to the decline of the organic layer, growing importance of the calcareous subsoil, and, as a consequence, formation of limnic rendzinas. In the post-lacustrine catena, the sequence of soils reflects the processes of lake filling with sediments and its transformation to a fen. The pedological processes triggered by drainage at different stages of lake terrestrialisation affect the stratigraphy of horizons and soil properties. Due to a different character of organic matter (detritus, peat, mursh, humus), the soils developed from calcareous gyttjas and the murshic soils underlaid with calcareous gyttja should be differentiated. The presence of the layer of calcareous gyttja near the surface determines soil properties caused by high concentration of $\mathrm{CaCO}_{3}$. Mixing of the layer with the overlying horizon, e.g. mursh or colluvium, causes a decrease in the thickness of gyttja itself and an increase in the content of $\mathrm{CaCO}_{3}$ in the surface horizon resulting in its alkalinity. Difficulties in systematizing the described soils reveal imperfections of soil systematics (mainly PSC 5). The lacustrine genesis of parental material, such as calcareous gyttja, is lost to quantitative parameters. Due to the high reactivity of $\mathrm{CaCO}_{3}$ in calcareous gyttja, limnic rendzinas should be qualified with a calcium carbonate content $>20 \%$. Thus, , calcareous mollic" should also contain $>20 \% \mathrm{CaCO}_{3}$. In the black earths, a « calcareous « subtype should be formed, including both primary and secondary carbonates. $\mathrm{CaCO}_{3}$ content is a decisive factor in the properties of calcareous post-lake soils and as it modifies them, it is inappropriate to classify these soils as gleysols.

\section{REFERENCES}

Alexandrowicz W.P., 2007. Malacofauna of the Late Glacial and Holocene calcareous lake deposits in Norhern Poland. Geologia 33(4): 395-420 (In Polish with English summary).

Alonso-Zarza A.M., Wright V.P., 2010. Palustrine Carbonates [In:] Carbonates in Continental Settings, Facies, Environments, and Processes. (Alonso-Zarza A.M., Tanner L.H., Eds.). Developments in Sedimentology 61: Elsevier Science Amsterdam, London: 103-131.

Chmieleski J., 2006. Pedological Investigation and Classification of Central-European Gyttjas). (PhD-thesis) HumboldtUniversität, Berlin, Germany: 196 pp.

Dean W.E., 1999. The carbon cycle and biogeochemical dynamics in lake sediments. Journal of Paleolimnology 21: 375393.

Dean W.E., Fouch T.D., 1983. Lacustrine environment. [In:] Carbonate Depositional Environments (Scholle P.A., Bebout D.G., Moore C.H., Eds.), AAPG Memoir 33: 97-130.

De Boever E., Brasier A., Foubert A., Kele S., 2017. What do we really know about early diagenesis of non-marine carbonates? Sedimentary Geology 361: 25-51.

Dobak P., Wyrwicki P., 2000. Impermeable properties of lacustrine chalk. Przegląd Geologiczny 48(5): 412-415.

Freytet P., Verrecchia P., 2002. Lacustrine and palustrine carbonate petrography: an overview. Journal of Paleolimnoly 27: 221-237.

Frąckowiak H., Feliński T., 1994. Decrease of the surface of meadow organic soils under conditions of intense desiccation. Wiadomości Instytutu Melioracji i Użytków Zielonych 18(2): 29-35 (In Polish with English summary).

Gierlowski-Kordesch E.H., 2010. Lacustrine Carbonates. [In:] Carbonates in Continental Settings, Facies, Environments, and Processes. (Alonso-Zarza A.M., Tanner L.H., Eds.). Developments in Sedimentology 61: Elsevier Science Amsterdam, London: 1-101.

IUSS Working Group WRB, 2015. World Reference Base for soil resources 2014. International soil classification system for naming soils and creating legends for soil maps. Update 2015. World Soil Resources Report 106. FAO, Rome: 188 pp.

Jarnuszewski G., 2015. Chemical properties of organic soils developed from lacustrine chalk near the lakes Strzeszowskie, Sitno, and Sierakowo (Western Pomerania, north Poland). Soil Science Annual 66(4): 168-179.

Jarnuszewski G., 2016. Characterization of some physical and chemical properties of post-bog soils developed from limnic deposits in vicinity of lake Dubie (Western Pomerania, NW Poland). Soil Science Annual 64(1): 24-31.

Kirk G., 2004. The biogeochemistry of submerged soils. John Wiley \& Sons: 304 pp.

Konecka-Betley K, Stefaniak P., 1983. Genesis and typology of soils formed from the lake chalk of the southern strip of swamps in the Kampinos Primeval Forest. [In:] Influence of human activity on the soil environment in the Kampinos National Park Wyd. SGGW Warszawa: 202-213. (In Polish with English summary). 
Kowaliński S., Licznar E., 1986. Humus compounds in rendzina soils formed out of limestones of different geological formations. Roczniki Gleboznawcze - Soil Science Annual 37(23): 159-167. (In Polish with English summary).

Krzywonos K., 1992. Organogenic carbonaceous soils on lacustrine chalk - characteristics and classification. Wiadomości IMUZ 17(3): 37-55. (In Polish with English summary).

Krzywonos K., 1993. Physical and hydrological characteristics of mineral-moorsh carbonaceous soils on lacustrine chalk. Wiadomości IMUZ 17(3): 57-77.

Kuźnicki F., Skłodowski P., 1976. Content and characteristics of the forms of humus compounds in rendzinas developed from carbonate rocks of different geological age. Roczniki Gleboznawcze - Soil Science Annual 27(2): 127-136. (In Polish with English summary).

Lemkowska B., Piaścik H., 2006. Differentiation of fens in landscapes of the Mazurian Lakeland. Polish Journal of Environmental Studies 15(5D): 43-46.

Lemkowska B, Sowiński P., 2008. Evolution of ,post-lake rendzinas" in the landscape of the Mazurian Lakeland. Roczniki Gleboznawcze - Soil Science Annual 59(1): 134-140. (In Polish with English abstract).

Lemkowska B., Sowiński P., 2009. Microelements in the soils of post-lake midmoraine depressions in the Olsztyn Lakeland. Zeszyty Problemowe Postępów Nauk Rolniczych 540: 237245. (In Polish with English abstract).

Lemkowska B., Sowiński P., Pożarski K., 2010. Changes in soil trophic conditions as a treat to natural functions of the Ustnik reserve. Woda-Środowisko-Obszary Wiejskie 29(1): 73-87. (In Polish with English abstract).

Lemkowska B., Orzechowski M., Smólczyński S., 2013. Differentiation of fens base in the Great Mazurian Lakes Region according to terrain morphogenesis. [In:] Environment soil formation and soil of river valleys (Jonczak J., Florek W., Eds.). Bogucki Wydawnictwo, Poznań: 95-102. (In Polish with English abstract).

Lemkowska B., 2015. Differentiation of fen bedrock in the Ełk Lakeland (NE Poland) in relation to late Pleistocene terrain morphogenesis. Soil Science Annual 66(4): 161-167.

Lemkowska B., 2016. Differentiation of fen bedrock in the Mrągowo Lakeland (NE Poland) in relation to Pleistocene terrain morphogenesis. Soil Science Annual 67(2): 57-63. (In Polish with English abstract).

Maciak F., Liwski S., 1972. Low peat decomposition intensity under influence of different organic and mineral substances. Roczniki Gleboznawcze - Soil Science Annual 23(1):139151. (In Polish with English abstract).

Marcinek J., 1976a. Division of hydromorphic formations based on the content of organic matter, calcium carbonate and clay fraction. [In:] Rules and criteria for mud and silt works as well as cartography of hydromorphic soils. Materiały Konferencyjne PTG Warszawa 5(32): 14-36. (In Polish).

Marcinek J., 1976b. Effect of drainage connected with the agriculture and forestry intensification on soil transformation. Zeszyty Problemowe Postępów Nauk Rolniczych 177: 73157. (In Polish with English summary).

Marcinek J., Spychalski M., 1976. Murshic calcareous soils of the Obra valley - characteristics and classification. [In:] Rules and criteria for mud and silt works as well as cartography of hydromorphic soils. Materiały Konferencyjne PTG Warszawa 5(32): 74-104. (In Polish).
Marcinek J., Spychalski M., 1998. Degradation of organic soils in Obra river valley after their drainage and many year agricultural use. Zeszyty Problemowe Postępów Nauk Rolniczych 460: 219-236. (In Polish with English summary).

Markowski S., 1971. Initial investigations of shrinkage of gyttja sediments. Zeszyty Problemowe Postępów Nauk Rolniczych 107: 73-84. (In Polish).

Markowski S., 1980. Structure and properties of peatlands bottom lake sediments of frequent occurrence in west Pomerania region as a basis for their identification and classification. [In:] Post conference materials lacustrine chalk and gyttja, Gorzów Wielkopolski-Zielona Góra: 45-55. (In Polish).

Meller E., 2004. Some chemical properties of gyttia-muck soils subjected to different utilization from the vicinity of Miedwie lake. Roczniki Gleboznawcze - Soil Science Annual 55(3): 139-146. (In Polish with English summary).

Meller E., 2006. Shallow organogenic-caclareous soils on lacustrine chalk and their transformation resulted from cultivation. Akademia Rolnicza w Szczecinie, Rozprawy 233: 1-115. (In Polish with English summary).

Olkowski M., 1967. Some chemical and physical properties of gyttja some dried Mazurian lakes. Zeszyty Naukowe WSR Olsztyn 23: 245-262. (In Polish).

Olkowski M., 1971a. The bulk denisity formation in organic and murshic soils of peatlands and the gyttjalands of the Mazurian Lakeland. Zeszyty Naukowe WSR Olsztyn 27(801): 93-108. (In Polish).

Olkowski M., 1971b. The development of habitat conditions and vegetation of the gyttjalands of the Mazurian Lakeland and the possibility of using them as meadow facilities. Zeszyty Problemowe Postępów Nauk Rolniczych 107: 27-46. (In Polish)

Petelski K., Sadurski A., 1987. Lake chalk indicator Holocene exchange of groundwater. Przegląd Geologiczny 3: 143-147. (In Polish with English summary).

Piaścik H., 1977. Changes of calcium, iron and aluminum content in peat-muck soils of the Mazurian Lakeland. Zeszyty Naukowe ART. Olsztyn, Rolnictwo 23: 1-60. (In Polish with English summary).

Piaścik H., Lemkowska B., 2004. Genesis of fens in the Masurian Lakeland. Telma 34: 31-37. (In German with English abstract).

Polish Soil Classification (Systematyka Gleb Polski), 2011. Roczniki Gleboznawcze - Soil Science Annual 62(3): 1-193. (In Polish with English summary).

Prusinkiewicz Z., Noryśkiewicz B., 1975. Geochemical and paleopedological aspects of the origin of lake chalk as the parent rock for the northern Poland rendzinas. Acta Universitatis Nicolai Copernici, Geografia 35: 115-137.

Rutkowski J., 2007. Lake settlements in Poland. Characteristics and state of diagnosis, research methodology, proposals. Studia Limnologica et Telmatologica 1(1): 17-27. (In Polish).

Rzepecki P., 1983. Classification and main lithological types of lake sediments. Geologia 9(1): 73-94. (In Polish).

Rzepecki P., 1985. Lacustrine calcareous deposits of Northern Poland between Łyna and Brda rivers. Geologia 11(3): 5-78. (In Polish with English summary).

Stabel H.-H., 1986. Calcite precipitation in Lake Constance: Chemical equilibrium, sedimentation, and nucleation by algae. Limnol. Oceanogr. 31: 1081-1093. 
Schnurrenberger D., James Russell J., and Kelts K., 2003. Classification of lacustrine sediments based on sedimentary components. Journal of Paleolimnology 29: 141-154.

Skwierawski A., 2011. The Causes, Extent and Consequences of Lake Drainage in the Olsztyn Lakeland in the 19th and Early 20th Century. [In:] Koc J., editor. Environment Alterations Research and Protection Methods. Olsztyn, University of Warmia and Mazury: 33-52 (In English).

Sowiński P., Lemkowska B., 2010. Macro-elements in soils of post-lake depressions of the Olsztyn Lakeland. Roczniki Gleboznawcze - Soil Science Annual 61(2): 87-94. (In Polish with English abstract).

Stasiak J., 1963. History of Kruklin lake as revealed by the deposits of its littoral zone. Warszawa. Prace Geograficzne Wydawnictwo Geologiczne 42: 94 pp. (In Polish with English summary).

Stasiak J., 1971. Genesis of sedimentation basins on outwash plains. Zeszyty Problemowe Postępów Nauk Rolniczych 107: 103-112. (In Polish with English summary).

Treese K.L., Wilkinson B.H., 1982. Peat-marl deposition in a Holocene paludal lacustrine basin - Sucker Lake, Michigan. Sedimentology 29: 375-390.

Uggla H., 1956. General characteristics of the soils of the Masurian Lakeland. Zeszyty WSR Olsztyn 1: 15-54. (In Polish with English summary).

Uggla H., 1964. The Influence of the drainage area on the formation and some properties of the lake sediments. Zeszyty Naukowe WSR Olsztyn 17 (355): 645-654. (In Polish with English summary).

Uggla H., 1969. Gyttja soils of the Mazurian Lakeland I. General characteristics of gyttja soils and gyttja-murshic soils. II. Physical, chemical and biological properties of gyttja soils and gyttja-murshic soils. Zeszyty Naukowe WSR Olsztyn, 25(3): 563-606.

Uggla H., 1971. Characteristics of gyttja and gyttja soils of Mazurian Lakeland in light of hitherto investigations of the Chair of Pedology, College of Agriculture in Olsztyn. Zeszyty Problemowe Postępów Nauk Rolniczych 107: 13-25. (In Polish with English summary).

Uggla H., 1976. Rendzinas in the Mazurian Lakeland. Roczniki Gleboznawcze - Soil Science Annual 28(2): 113-125. (In Polish with English summary).

website 1: https://docs.google.com/viewer? $\mathrm{a}=\mathrm{v} \& \mathrm{pid}=\mathrm{si}$ tes\&srcid=ZGVmYXVsdGRvbWFpbnxrbGFzeWZpa2FjamFnbGVifGd4OmMxNjg1ZGI4NmQyMzMwOQ,
Systematyka gleb Polski, 6 wydanie (The classification of Polish soils $6^{\text {th }}$ edition), 2019.

Więckowski K., 1993: Sedimentation processes and rate of accumulation of bottom sediments in selected lakes. [In:] (edit. I. Dynowska) Changes in water relations in Poland as a result of natural and anthropogenic processes. Kraków 88-97. (In Polish with English summary).

Więckowski K., 2009. Issues of genesis, age and evolution of lakes in particular regions of Poland in the light of research on their bottom sediments. Studia Limnologica et Telmatologica Sup. 1: 29-72. (In Polish with English summary).

Wyrwicki R., 2001. Holocene carbonate sediments: properties and chemistry of gel, composition of liquid and solid components. Przegląd Geologiczny - Polish Geological Review 49(6): 525-532. (In Polish).

Wyrwicki R., 2003. Has lacustrine chalk originated in freshwater environment? Przegląd Geologiczny 51(6): 483-488. (In Polish).

Zawadzki S., 1957. Investigations on the origin and evolution of bog soils rich in calcium carbonate in the Lublin District. Annales Universitatis Mariae Curie-Skłodowska Lublin Polonia sectio E: 1-79. (In Polish with English summary).

Żurek-Pysz U., 1992. Strength and deformability of an organiccalcareous lacustrine deposit (gyttja) in relation to its water content and colloid content. Bulletin of the International Association of Engineering Geology 45: 117-126. (In Polish with English summary).

Żurek-Pysz U., 1998. Gyttja lithological indicators in reference to their geological and engineering properties. [In:] (edit. J. Liszkowski) Mat. Conf. Contemporary Problems of Engineering Geology in Poland. (In Polish with English summary).

Żurek-Pysz U., 2001. Diagenetic microstruktural changes in lacustrine chalk caused by long-lasting loading. Minarological Society of Poland - special papers 18: 230-233.

Żurek-Pysz U., 2007. A spacial lithological indexes of holocene lacustrine chalk. Geologos 11: 321-329. (In Polish with English summary).

Żurek-Pysz U., Skalski G., 2003. Litological variety of bio- and chemogenic sediments on example of choosen profile from Grabowo deposit (Middle Pomerania). Geologia i geomorfologia 5: 173-186. (In Polish with English summary).

Received: April 26, 2018

Accepted: August 1, 2018

Associated editor: t. Uzarowicz

\section{Rędziny pojeziorne Pojezierza Mazurskiego}

Streszczenie: Od XIX wieku na Pojezierzu Mazurskim spuszczano wodę z płytkich jezior w celu pozyskania nowych gruntów pod uprawy. W wyniku przeprowadzanych prac hydrotechnicznych obniżono poziom wody o około 6 m. Dzięki temu osady denne jezior przekształcono w gleby pojeziorne wykorzystywane rolniczo. Część z nich, powstała z gytii węglanowej nazywana jest rędzinami pojeziornymi, jednakże przyporządkowanie tych gleb do jednostek Sytematyki Gleb Polski jest niejasne. W przypadku, kiedy miało miejsce naturalne lądowienie jeziora, gytie przykrywa warstwa torfu lub murszu. Uformowane nowe gleby podlegają ewolucji, jej kierunek zależny jest od sekwencji utworów w profilu, murszenia materii organicznej oraz modyfikujących procesów namulania i deluwialnego. W pracy przedstawiono zróżnicowanie rędzin pojeziornych Pojezierza Mazurskiego na przykładzie obiektów Pęglity, Jęcznik, Kruklin, Malinowo, Wynki oraz Ustnik. Zaproponowano nowe podtypy do kolejnej edycji Systematyki Gleb Polski.

Stowa kluczowe: gytia węglanowa, rędziny pojeziorne, Pojezierze Mazurskie 